\title{
The Utilization of Geographic Information System in Rural Development
}

\author{
Nurjati Widodo* \\ Department of Public Administration \\ Universitas Brawijaya \\ Malang, Indonesia \\ *nurjati_fia@ub.ac.id
}

\begin{abstract}
Geographic Information System (GIS) is one of the ICT developments that can support development, including development at the rural level. The research was conducted in Banyuwangi Regency. This study aims to analyze the utilization of geographic information systems in rural-level development through the E-Monitoring System application. Besides, it also analyzes the inhibiting factors in the use of geographic information systems at rural-level development.
\end{abstract}

Keywords-GIS, geographic information system, rural development

\section{INTRODUCTION}

The government and the community have carried out rural development in Indonesia until now through various policies and programs that have been determined. These efforts have resulted in various advances felt by some rural communities. However, there are still many rural areas that have not developed as fast as other regions.

According to Dwijowijoto [1], development is a colossal activity, takes a long time, involves all citizens and the international community, and absorbs almost all nation-state resources. Therefore, the entire development process must go through good management. It is reinforced that generically this process starts with planning, is followed by implementation, and ends with control.

Law of the Republic of Indonesia Number 6 of 2014 concerning Villages [2] states that village development has the aim of improving the welfare of rural communities and the quality of human life as well as poverty alleviation through meeting basic needs, building village facilities and infrastructure, developing local economic potential, and utilizing natural and sustainable environmental resources. There are three stages at the stage of village development, namely Planning, Implementation, and Supervision. Village development has the principle of promoting togetherness, kinship, and cooperation to realize peace and social justice.

Rural development is an important part of national development, given that rural areas are still dominant. Data from Central Bureau of Statistics in 2020 states that $82 \%$ of
Indonesia's territory is rural, and around $44 \%$ of Indonesia's population still lives in rural areas. This makes rural development in Indonesia multi-dimensional and multisectoral. Therefore, it is necessary to integrate and link various dimensions and sectors in its implementation, including, in this case, the use of Information and Communication Technologies (ICTs).

In the era of technological advancement, the government needs to innovate in providing electronic-based information. Presidential Regulation of the Republic of Indonesia Number 9 of 2018 concerning "Sistem Pemerintahan Berbasis Elektronik" (SPBE) explains that in order to realize clean, effective, transparent, and accountable governance as well as quality and reliable public services, an electronic-based government system is needed, or the general term calls it electronic government. This shows that information technology as part of an electronic system is an important factor in supporting transparency, especially in village development implementation. One of the information technologies that can be utilized in providing information on the implementation of village development is the Geographic Information System.

Geographic Information System (GIS) is one of the ICT developments that can assist in supporting development. GIS is a computer-based information system specifically designed to manage data that contains spatial information. Aronoff [3] defined a GIS is a computer-based system that provides the following four sets of capabilities to handle geo-referenced data: (1) input; (2) data management (data storage and retrieval); (3) manipulation and analysis; and (4) output.

According to Sjafrizal [4], GIS is an information technology that can analyze, store, and display both spatial and non-spatial data by combining the power of relational database software and Computer-Aided Design software packages. According to ESRI [5], a complete GIS includes various components and technologies used, namely hardware, software, spatial data, and organizational structures. Furthermore, GIS can obtain, store, update, manipulate, analyze, and display all forms of geographically referenced information (Figure 1). This system focuses on spatial and nonspatial (tabular) based data management. This system has good 
use-value in various sectors, one of which is development planning. Examples of its application are transmigration settlement planning, regional spatial planning, urban planning, location planning, industrial relocation, markets, settlements, etc.

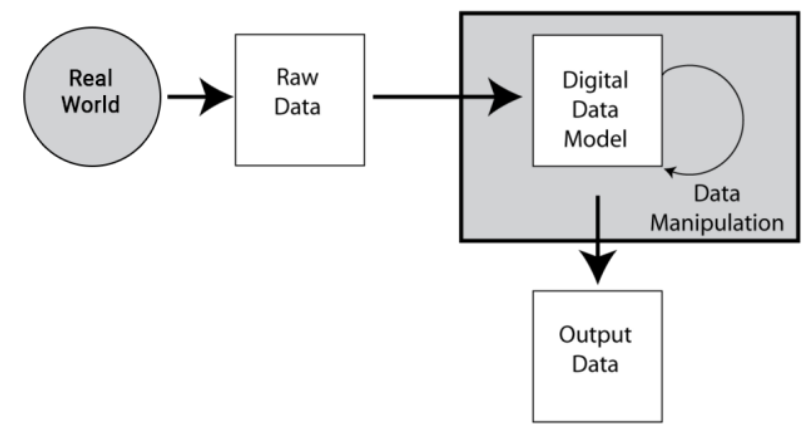

Fig. 1. The GIS process [6].

The Geographic Information System's application is also supported by Law Number 4 of 2011 concerning Geospatial Information [7], which explains that the goal is to encourage the use of geospatial information in government administration and various aspects of community life. With such a wide implementation and supported by a strong legal basis, it is not impossible that GIS can also be used for development program activities at the village level.

\section{Methodology}

This type of research used in this research is descriptive research with a qualitative approach. This research was conducted in Banyuwangi Regency by looking at the system's utilization at the village level using Bangsring Village, which is one of the villages in Kecamatan (SubDistrict) Wongsorejo with the highest number of development activities in 2019, namely 44 activities. Data collection techniques used were observation, interviews, and documentation. Analysis of the data used in this study using the Creswell model. According to Creswell [8], this model analysis illustrates a linear and hierarchical approach built from the ground up and a more interactive approach.

\section{RESULTS}

In the current digital era, it has opened new insights into the development of GIS technology. Map management using computers is often used so that maps can be processed properly and quickly. Geographical data processing like this can only be done by using GIS. The use of computers also provides high speed, and data manipulation can be done quickly because the data only needs to be updated through the analysis formula and without changing the original data in an existing base map.

GIS implementation is beneficial in monitoring rural development programs. The Banyuwangi Regency Government has initiated this by building a system called the E-Monitoring System (EMS). The E-Monitoring System is a monitoring system for development plans at the village level integrated into a network or online system. The application of this system applies to all villages in Banyuwangi Regency, as many as 217 villages.

The Banyuwangi Regency Government, through the Village Community Empowerment Service, provides a forum to the village government in providing information regarding the implementation of development in each village in an integrated manner. The system involves various relevant stakeholders to monitor and assess the entire development process from the preparation stage to completion by utilizing internet technology effectively and in real-time.

Banyuwangi Regency is the only local government in Indonesia that applies a geographic information system in monitoring village-level development through the EMonitoring System. This system managed to occupy the top 6 in the Geospatial Information Utilization Innovation competition organized by the Geospatial Information Agency in 2017.

As stated on the official website of the E-Monitoring System http://ems.banyuwangikab.go.id, this system can also be used to detail and check the target of the use of funds. This monitoring was carried out to ensure that village funds disbursed were right on target and used appropriately. Operationally, the E-Monitoring System is managed by the department and each sub-district in Banyuwangi Regency.

Based on researchers' observations, the construction of the E-Monitoring System was because the Banyuwangi Regency Government had problems gathering information in the form of development progress and absorption of funds from each village. The purpose of building this system is to increase effectiveness and efficiency, especially concerning time. As an illustration, the use of information collection methods before the E-Monitoring System's existence still uses conventional survey methods, more precisely using the sampling method. This system is considered more time-consuming because direct observations must be made at village points where development activities are found. Besides that, the vulnerability level to fraud in the development process is high because this method takes a sample of $50 \%$ of the number of villages in one sub-district, meaning if one sub-district has 10 villages, then 5 villages are taken as samples. This causes villages not sampled to have a great chance of committing fraud in the development process.

The E-Monitoring System is an application run by the Banyuwangi Regency Government through the Community and Village Empowerment Service. The E-Monitoring System (EMS) or e-Village Monitoring (e-VM) is used to oversee development programs in villages, both physical and nonphysical programs, with more than 4,000 programs in 189 villages in the eastern tip of Java Island.

The sub-district will take photos of the program implementation, for example, for road construction ranging from 0 percent (road conditions have not been repaired) to 100 
percent (roads have been repaired). It can be concluded that the E-Monitoring System is a system to monitor the development of development activities in all villages in Banyuwangi Regency both physically by taking photos of the implementation of development from zero to completion.

Development monitoring is essential to consider in observing development programs' success from the central to regional levels. EMS is a web-based application that monitors infrastructure development in village environments transparently based on geographic information systems. This system requires all sub-districts to manage development monitoring in each village. EMS is an application that specifically monitors physical development. This is because physical developments are considered easier to monitor their progress.

Village level development monitoring using the EMonitoring System basically refers to the Minister of Home Affairs Regulation Number 114 of 2014 concerning Village Development Guidelines [9]. More precisely, the stages of the implementation of activities include the inspection stage for the implementation of Village infrastructure activities and changes in the implementation of activities.

The EMS interface displays a map of the entire Banyuwangi Regency area divided into several parts. Each of these sections has an administrative boundary that represents the sub-district in Banyuwangi Regency. A search column functions to perform commands to display data according to the district and the year the development program is running. The data is shown in spatial data, which contains the coordinates of the construction location on the map. The Login menu on the top right is for Community and Village Empowerment Service officers and operators in each subdistrict. This menu functions to change the data in the EMS application.

This stage's urgency is based on the focus of the Banyuwangi Regency Government Service in the role of monitoring village development in terms of physical activities. This is reinforced by the presence of photo documentary evidence as a reference in monitoring physical activities. Community involvement is also considered in supporting the monitoring of village activities. The community is given the authority to monitor and submit complaints if there is a mismatch in the implementation of the results of monitoring activities.

After the E-Monitoring System was implemented, in general, there was no significant change to the inspection of Village infrastructure activities in Bangsring Village. This can be seen in the village head and the Village Infrastructure Inspection Team, which are still the key actors in the successful inspection of village infrastructure activities. The involvement of the Kecamatan is more emphasized in helping to supervise the implementation of infrastructure activities in Bangsring Village. The sub-district has the task of being a technical operator that accommodates all infrastructure activities in all villages in Wongsorejo District, Bangsring Village. The sub- district involvement does not have a major influence on the roles of the Village head and the Village Infrastructure Inspection Team. This is because the sub-district only conducts observation activities on developing the implementation of Village activities and reports the results of observations by inputting them into the E-Monitoring System.

Basically, the E-Monitoring System provides information related to the progress of the implementation of Village activities. The information provided is in the form of observations from the sub-district that show the development of activities at:

- The first stage, examination of the pre-implementation stage of activities at the $0 \%$ (zero percent) stage;

- The second stage, inspection of the activity implementation stage at the $50 \%$ (fifty percent) stage and

- The third stage, examination of the post-implementation stage of activities at the $100 \%$ (one hundred percent) stage.

The existence of photo documentation makes the inspection process for Village infrastructure activities more transparent. Regarding the photo taking technique, the Village Infrastructure Activity Inspection Team took the photos at the same angle starting from the pre-implementation stage until the activity was declared complete. This is necessary to ensure data transparency to the general public, especially the village head as a user. Taking photo documentation is done by going directly to the field.

Implementing the E-Monitoring System uses a geographic information system approach in presenting development monitoring data in all villages in Banyuwangi Regency. This can be seen from the use of spatial and tabular based data. Spatial data is needed to provide a spatial description of the data. One of the implementations of spatial data is the formation of digital maps.

Map coordinates are crucial in spatial data to support the data's accuracy displayed through the E-Monitoring System. The placement of coordinate points on the digital map plays a role in determining the location point of ongoing Village infrastructure activities. The impact that was felt was the opening of opportunities for the community to participate in the direct inspection of infrastructure activities. This opens up the possibility to increase the level of community participation in supervising Village development

The coordinate point can be found through photos taken during the inspection of infrastructure activities. This depends on the communication device's features, namely the Global Positioning System (GPS). If the device has this feature and is activated by the user, the coordinates can be read automatically. The location is placed after the coordinates have been identified. With the help of Google Maps (maps.google.com) as a digital maps provider, the operator will input the system's coordinates. The location of the village 
infrastructure activities can be known directly. Based on these points, technical operators input coordinate points on the EMonitoring System and ensure compliance with Google Maps. This impacts the completion of the technical operator's task of the E-Monitoring System, which is less efficient because they have to input data on two different systems with the same digital map base.

E-Monitoring System can be likened to a forum for the community to be involved in monitoring village development. The community's role in Bangsring Village becomes more open to providing considerations regarding changes in the implementation of Village infrastructure activities to stakeholders. This can be done without reducing the mechanisms that have been implemented. The community can directly coordinate with the Village Infrastructure Activity Check Team or directly with the Bangsring Village Head. However, until now, there has been no intermediary who can directly bridge the public's opinions to stakeholders because the E-Monitoring System does not have a feature that can accommodate this.

The clarity of the EMS legal basis is the first limiting factor. The implementation of monitoring using EMS requires a clear legal basis to have proper guidance and direction. The legal basis is also binding so that the stakeholders involved can be more responsible for their respective duties and functions.

The second limiting factor is the low awareness of EMS system maintenance. Good maintenance can maintain the continuity of a system's performance to provide the best service to its users. One of the effects of the lack of system maintenance is that operators' constraints in the field are inaccessible map displays. This makes the operator unable to input coordinate point data on the map view.

\section{DISCUSSION}

\section{A. Utilization of GIS in Village Level Development}

To realize good governance, the Banyuwangi Regency Government, through the Community and Village Empowerment Service, is trying to make innovations to increase the effectiveness and efficiency of inspection of village infrastructure activities through the concept of eGovernment. E-Government is defined as the application of Information Technology (IT) in government that aims to make the work process within the wheels of government simpler, more responsive, accurate, and transparent. One form of eGovernment is the E-Monitoring System. The system is tasked with displaying information to the community regarding implementing village activities throughout the Banyuwangi Regency. In the concept of development control and evaluation, according to Sjafrizal [4], these activities are carried out to ensure that the implementation of programs and activities is following the plan and also receive input for improving future planning. From this, it can be seen that a program and activity can be carried out well. On the other hand, some programs and activities have failed in their implementation.

The application of the E-Monitoring System compared to the manual mechanism based on the Minister of Home Affairs Regulation No. 114/2014 concerning Guidelines for Village Development [9] has no significant changes. There is only a change in the addition of the Activity Inspection Team's role, namely assisting sub-district operators in operating the EMonitoring System. This is following Law Number 23 of 2014 concerning Regional Government, which explains that the subdistrict head assisted by the sub-district apparatus has the duty to guide and supervise the implementation of Village and/or sub-district activities. The collaboration between village and sub-district officials is a form of guidance from the sub-district in monitoring village development to encourage the empowerment of village communities. This is reinforced by Government Regulation Number 19 of 2008 concerning the District [10], the role of the sub-district head in fostering village administration assisted by sub-district apparatus has the task of providing guidance, supervision, facilitation, and consultation on the implementation of the village and/or kelurahan administration. This regulation's impact is the granting of rights to village officials to get comprehensive assistance from the sub-district so that they can run the EMonitoring System to its full potential.

Updates to geographic data can make data quite dynamic. This is reinforced by Paryono's opinion in Iqbal [11], which explains that GIS cannot be viewed as a development from conventional maps to digital maps only. Along with the ability to manipulate and analyze data, GIS can produce valuable information that can be used as new input for other data analysis by the concept of the information life cycle.

\section{B. Inhibiting Factors in Utilizing GIS at Village Level Development}

Based on the previous presentation, there is no regional head regulation that specifically regulates the E-Monitoring System. The legal basis affects a policy when viewed from the law's strength and certainty that binds it. This is not found in EMS because it does not have a specific legal basis.

On the other hand, the making of regional head regulations can be carried out based on the related institutions or agencies' needs, namely the Dinas Pemberdayaan Masyarakat dan Desa (DPMD) Banyuwangi Regency. This causes the legal force based on Law Number 6 of 2014 and Regulation of the Minister of Home Affairs Number 20 of 2018 to be considered weak because it is too broad. Basic legal constraints in this area hamper village level development monitoring using the EMonitoring System.

In the second inhibiting factor, there are GIS system maintenance procedures not fully implemented by service providers. This results in constraints, namely, the digital map display cannot be accessed by the user and makes the operator unable to input coordinate point data on the map display. 
The main reason is that the serial key, which is a combination of numbers and letters, has not been updated, issued by the digital map provider, namely Google Maps, within a certain period of time to the GIS service provider. The serial key functions to reactivate the map display and provide access to operators to input coordinate points so that the disturbance hinders the operator's performance from carrying out their duties properly.

Prahasta [12] explains that using and maintaining a GIS system and its database is still very much needed. Most GIS databases are dynamic, changing almost daily, and users will immediately think of additional applications that should be developed in the existing system. Formal procedures are required to manage maintenance and data updating activities to ensure successful GIS system operations.

\section{CONCLUSION}

Utilization of the E-Monitoring System uses a geographic information system approach in presenting development monitoring data in all villages in Banyuwangi Regency, which uses spatial and tabular data. The map coordinates can support the accuracy of the data displayed through the E-Monitoring System. The mechanism for changing the implementation of existing Village infrastructure activities has not undergone significant changes. With the existence of the E-Monitoring System, the community's role in Bangsring Village becomes more open to providing considerations regarding changes in the implementation of Village infrastructure activities to stakeholders.

The use of Web-Based Geographic Information Systems has been implemented in the E-Monitoring System. It has currently been published freely by the Banyuwangi Regency Government so that clients can access it via the http://ems.banyuwangikab.go.id page. However, no Local Government regulation specifically regulates the village-level development monitoring mechanism using the E-Monitoring System. Low awareness of system maintenance was also an identified limiting factor. This can be seen from the absence of formal procedures in managing maintenance activities and updating data to ensure E-Monitoring System operations' success. The Office of Communication, Information, and Encryption of Banyuwangi Regency as the application provider should carry out regular and continuous system maintenance and promote effective and efficient coordination.

\section{REFERENCES}

[1] D. Riant, Reinventing Pembangunan: Menata Ulang Paradigma Pembangunan untuk Membangun Indonesia Baru dengan Keunggulan Global. Jakarta: PT Elex Media Komputindo, 2003.

[2] Law of the Republic of Indonesia Number 6 of 2014 concerning Villages.

[3] S. Aronoff, Geographic Information Systems: A Management Perspective. Ottawa, Canada: WDC Publications, 1989

[4] Sjafrizal, Perencanan Pembangunan Daerah dalam Era Otonomi. Jakarta: PT. Raja Grafindo Persada, 2014.

[5] ESRI, Understanding GIS: The Arc/Info Method Environmental System. California Research: Institute, 1990.

[6] D. Martin, Geographic Information Systems: Socioeconomic Applications (Second edition). London: Routledge, 1995.

[7] Law of the Republic of Indonesia Number 4 of 2011 concerning Geospatial Information.

[8] J.W. Creswell, Research Degisn. Yogyakarta: Pustaka Pelajar, 2017.

[9] Regulation of the Minister of Home Affairs of the Republic of Indonesia Number 114 of 2014 concerning Guidelines for Village Development.

[10] Republic of Indonesia Government Regulation Number 19 of 2008 concerning Districts.

[11] M. Iqbal, Perencanaan Pembangunan Daerah Berbasis Sistem Informasi Geografis (GIS). Malang: Universitas Brawijaya, 2014

[12] E. Prahasta, Sistem Informasi Geografis: Konsep-Konsep Dasar. Bandung: CV Informatika, 2012. 